\title{
A Proposal to Achieve Financial Independence in Prince Sattam Bin Abdulaziz University in Accordance with the New System of Universities and Vision 2030
}

\author{
Mansour bin Zaid bin Ibrahim Al-Khathlan ${ }^{1}$ \\ ${ }^{1}$ Associate Professor of Higher Education Administration, Prince Sattam bin Abdulaziz University, 173 Alkharj \\ 11942, Saudi Arabia. \\ Correspondence: Mansour bin Zaid bin Ibrahim Al-Khathlan, Associate Professor of Higher Education \\ Administration, Prince Sattam bin Abdulaziz University, 173 Alkharj 11942, Saudi Arabia. \\ Received: January 2, 2020 \\ Accepted: February 3, 2020 \\ Online Published: February 6, 2020 \\ doi:10.5430/ijhe.v9n3p15 \\ URL: https://doi.org/10.5430/ijhe.v9n3p15
}

\begin{abstract}
The current research addresses an important educational and administrative issue. It is the financing of universities and the potential that the university can achieve its goals and strive to develop the society away from any pressures. It may face from private or governmental institutions which may participate in funding them with the aim of implementing the new Saudi universities system. All universities and educational institutions rely on their own resources and diversify new funding resources to alleviate the state budget in order to achieve the independence of these institutions and give them freedom to achieve their goals, and also the strategic goals of the 2030 Vision for Saudi Arabia. In order to achieve the research main objective, a questionnaire is distributed to the respondent to know the current reality of universities on the subject of funding. We find and propose a number of ways for the university to be financially autonomous.
\end{abstract}

Keywords: independence funding, saudi universities, new university system, vision 2030

\section{Introduction}

During the second half of the twentieth century, universities developed a new perspective on the relationship with their surrounding environments through the availability of funding resources for their activities and programs for consolidating the contact with economic activities which is linking scientific research to these activities, particularly the industry. When talking about the oldest universities in the world, such as Harvard and Stanford universities in the United States of America, about half of the funding resources for these universities come from government support and these large institutions cannot continue to operate without this support. In addition to its role in embracing innovations and science, the university plays a broader and more major role in attracting the talents and expertise necessary for the continuation of its career. The university must play a captivating role in attracting distinguished people in order to turn into a focus of enlightenment (Al-Harout, 2010).

The percentage of the government credits allocated to universities in the United States was $47 \%$ of the total number of credits and the rest of the credits are left to the university to be managed through the fees of scholars, and grants received by the university from donors and the services provided by the university (El-Sayed, 2003). Funding may be defined as the process of supplying or creating the money needed by using the best legitimate methods and sources. The main features that distinguish funding in the modern era is the diversity and multiplicity of resources and the lack of dependence on one resource. The funding is no longer limited to providing money only rather it has become more than that to the proper channeling of money and the safety of its exploitation and its preservation (Al-Zamil, 2018).

The Arab Organization for Education, Culture and Science indicated in an exclusive document that government funding represents more than $(90 \%)$ of the resources of higher education in the Kingdom of Saudi Arabia, and in 2014 the state support for education reached (210) billion Saudi riyals which is 25\% of the state budget (El-Dokki, 2015). Higher education in the Kingdom of Saudi Arabia gained a lot of attention from the state. Higher education in the Kingdom of Saudi Arabia has witnessed during the previous year's tremendous leaps and great developments as the number of universities in the kingdom has increased to 28 public universities by the year $1439 \mathrm{AH}$. including the 
newly established universities such as Prince Sattam Bin Abdulaziz is currently, Shaqra University, Majmaah University, Hafr Al-Batin University and Bisha University.

The most important strategic goals of Prince Sattam bin Abdulaziz University plan is to enhance the financial sustainability of the university by building a strategy for investment of university facilities, the continuous development of the university's endowments and the development of mechanisms to raise the efficiency of performance to reduce waste. The university's also keens to develop financial resources and to diversify its funding sources in order to achieve financial sustainability. (Prince Sattam bin Abdulaziz University Strategic Plan, 2018). Non-governmental sources are consisted of university's revenues in exchange of academic services, research consultancy, revenues from paid training programs, renting some of the university's facilities and housing payments are done by General Administration for Financial and Administrative Affairs at Prince Sattam bin Abdulaziz University. But, the most current funding is from government funding which is a traditional method of funding that most Saudi public universities are going to utilized.

Prince Sattam bin Abdulaziz University depends mostly on government funding, despite the presence of a number of other funding resources such as the Prince Abdul Rahman bin Nasser Institute for Research and Consulting Services, the Trust of the University Endowments, and the Deanship of Community Service. The budget of Prince Sattam bin Abdulaziz University is increasing the burden due to expansion of the university to serve the society in the Al-Kharj Governorate to Wadi Al-Dawasir. Due to the university's inability to diversify its sources of funds and to remain with the goals of the Kingdom's Vision 2030 and the National Transformation Program 2020, the present research seeks to find solutions to diversify funding sources.

The Ministry of Education has adopted a number of strategic goals through the National Transformation Program 2020. The most prominent are diversifying the innovative funding sources and improving the financial efficiency of the education sector to improve the educational environment and to raise the participation of the private sector in education. We aim to observe the financial independence of Prince Sattam bin Abdulaziz University in accordance with the new universities system, the 2030 vision for the Kingdom and in light of some international experiences.

\section{Literature Review}

The government of any country aims to diversify the sources of university funds instead of a sole reliance on the government resource. There are many types of funding resources in universities i.e. "public funding", "private funding" and " a mixture of both (Al-Majid, 2018; Al-Maliki, 2014; Al-Otaibi, 2004; Sherif, 2012). The third pattern, "mixed financing pattern", is distinguished from the sole governmental and sole private pattern. The justification for this funding pattern can be summarized by overcoming the defects of both other patterns. This pattern reduces the weaknesses of government funding or private funding. There are many benefits in the combination pattern which is an ideal solution for any public funding sector.

Supporters of this funding pattern believe that it would contribute to reduce the waste. It contributes to a financial independence for universities and to reduce costs to the state. Al-Majid (2018) indicates that many countries of the world have taken this pattern. For example, both the governmental and private sectors contribute to funding of American Universities. The percentage of government funding for American universities was $47 \%$ of their total budgets while the rest of the budget was left for universities to manage through fees, grants, gifts and donations. Al-Khazim (2018) states that public universities are accustomed every year to relying on the state's allocated budgets and this action has weakened their capability to think about developing their own resources and to diversify their funding sources as well.

Al-Fahad (2017) mentions that government expenditure on public and higher education reflects the state's interest in education. The percentage of government expenditure on government education in $1435 \mathrm{AH}$ was reached about $25 \%$ of the total approved budget. Al-Harbi (2015) indicates that the experience of Saudi universities in funding of non-governmental alternatives to fund their activities and programs are marginal and very small compared to self-funding. He believes that Saudi universities still rely heavily on the government funding. These allocations may be affected by the external economic conditions of the state and other conditions which affects the plans, programs and goals of these universities. There is a need to improve their financial efficiency by diversifying their funding resources and by developing self-resources which is also in line with the goals of the Kingdom's Vision 2030 and the National Transformation 2020 program.

Many universities worldwide depend on endowments as a funding resource. There are many successful models in the world in this field such as Harvard University's the total value of endowments reached more than 30 billion dollars in 2012 and the American University of Bell's the total endowment reached more than 19 billion dollars in 2012. 
The endowment revenues in the same year reached 93 million dollars in some other American universities. As a local example, King Saud University and King Abdulaziz University have emerged these local and international models to be benefited from these successful experiences of donations and grants (Maryam \& Al-Dabbasi, 2016). The university is considered one of the most important non-profit institutions which receive donations, grants and gifts. These donations are also a part of the contributions that community members provide to the university. The others are scholarships and sees (Al-Khazim, 2018), privatization (Al-Maliki, 2014; Al-Jumai, 2019).

Privatization is the transfer of economic activities owned by the university to the private sector. The economists believe that a solution to financial problems facing by the education sector in many countries is to privatize the education or some of its sectors. The university can privatize some of its sectors such as the housing sector, the health sector, printing press, or any other like Scientific Chairs (Bamakhurma \& Batih, 2008; Al-Maliki, 2014; El-Dokki, 2015). Scientific Chairs are a research or academic program at the university which aims to enrich knowledge and research production funded by a permanent or temporary cash grant donated by an individual, an institution or a company. Scientific or research chairs plays a significant role in the funding process in America and other countries. Huang (2016) mentions that diversification of funding resources in Japan has been done through multiple patterns and the most important of which is the contribution of universities' industrial sectors in funding through scientific chairs.

In Hong Kong, universities are funded based on the performance by examining plans issued by colleges and centers which based on the indicators through which these plans can be judged and relative weights formulated to assess various university activities related to education, scientific research, and communique services (Malpas, 2003). Universities in Thailand increase tuition fees and forming different partnerships with the private sector to increase their financial income (Rie, 2009). Argentina's universities make agreements with commercial and business organizations, increase the fees for graduate students to improve their budget and try to rely on non-government funding (de Fanelli, 2009). In Egypt, a study was presented which investigated a number of mechanisms to meet the funding challenges faced by a higher education sector (Shehata, 2006). A study on Sultanate of Oman is conducted to diversify the sources of university funding. Malaysian are tried to diversify their resources of income over a five-year period from 2006-2011 and their experience was summarized the non-government funding resources (Amran et al., 2014). Japanese universities carried out a profitable experience from 2000-2015 and they were able to achieve self-sufficiency to diversify funding resources of higher education.

There are also some attempts that were made at the level of Saudi universities or Arab universities. For example, Al-Zamil (2018) investigated the Imam Muhammad bin Saud Islamic University to identify the views of university leaders on the adequacy of self-funding alternatives at the university and his results showed that the alternatives were low and most of reliance was on government fund. In case of King Faisal University, the government fund represents the main source of university's funding and there are no alternatives to the university self-funding (Al-Hammadi \& Samah, 2017). A study also compares the universities' funding in the United Kingdom and in the Kingdom of Jordan. Another comparison conducted between funding sources of higher education in Britain and Saudi Arabia (Al-Tuwairqi, 2012).

To activate the role of knowledge economy at Prince Sattam bin Abdulaziz University, some studies worked on its financing process and suggested to develop scientific and applied knowledge in the university (Al-Wadhani, 2007) and to determine the existing knowledge, type, and location of the university (Al-Dawood, 2017). Moreover, Al-Hajji and Dokki (2015) advised to reconsider the current university majors and developing them in the future in order to comply with the needs of the labor market. There is a need to study the factors to reduce the dependence on government funding and to investigate the trend to diversify funding sources. Prince Sattam bin Abdulaziz University has made some attempts to diversify its funding resources including the establishing the endowment program for Prince Sattam bin Abdulaziz University (Ahmad \& Al-Dabbasi, 2016). But, still a gap is existing to find the most important factors of funding. So, the present study is trying fill this gap.

\section{Research Methodology}

To achieve the main research goal and its sub-goals, the research relied on the descriptive analytical approach. The research was based on the field study that included the distribution of questionnaires to the of the sample individuals and the statistical analysis program "SPSS" was used for data analyses. This research was based on the descriptive analytical approach for data analysis including frequencies, ratios, arithmetic mean, standard deviation. The research population was consisted of all 365 administrative officials (university president, deans, heads of administrative units), academic leaders (deans, agents) and financial management employees. The research sample consisted of 90 individuals from the whole population. Some characteristics are shown in table 1. 
Table 1. Iterations and percentages of demographic variables

\begin{tabular}{cccc}
\hline Variable & Answer & Repetition & Percentage \\
\hline \multirow{3}{*}{ Experience } & Less than 5 years & 17 & 18.9 \\
& From 5 to 10 years & 25 & 27.8 \\
& From 10 to 15 years & 32 & 34.4 \\
Job title & More than 20 years & 12 & 13.3 \\
& Academic leader & 34 & 37.8 \\
& Administrator & 28 & 31.1 \\
& Financial Management Officer & 28 & 31.1 \\
& Total & 90 & 100 \\
\hline
\end{tabular}

\section{From the previous table it is clear that:}

$13.3 \%$ of the research sample had their experience from 15 to less than 20 years, $62.2 \%$ of their experience was from 5 to less than 15 years and (5.6\%) their experience was more than 20 years and $18.9 \%$ of sample expressed their experience less than 5 years. The data was collected by a well-structured questionnaire. The questionnaire consists of two main parts including demographic data (experience, job title) and the targeted other questions including two axes.

Table 2. Cronbach Alfa

\begin{tabular}{ccc}
\hline Axis & No. of phrases & Method of Alfa Cronbach \\
\hline First axis & 20 & 0.88 \\
Second axis & 23 & 0.97 \\
Overall questionnaire (general stability) & 43 & 0.96 \\
\hline
\end{tabular}

Table 2 shows the Cronbach Alfa coefficients of statistical stability. It is cleared from the table results that all the stability coefficients of the axes are ranging between 0.88-0.97 which indicates that the research tool (the questionnaire) is characterized by great stability in order to achieve the research purposes and to make the statistical analysis sound and acceptable. The data was encoded and entered into the computer to determine the length of the cells of the five-meter scale (the lower and upper limits). The range $(5-1=4)$ was calculated, then divided by the number of cells of the scale to get the correct cell length, i.e. $(4 / 5=0.80)$. After that, this value was added to the lowest value in the scale (or the beginning of the scale which is the correct one) in order to determine the upper limit of this cell and the length of the cells in table 3.

Table 3. Cell length to explain mean averages

\begin{tabular}{ccc}
\hline Coding & Cell length & Approval degree \\
\hline 1 & $1.00-1.79$ & Very high \\
2 & $1.80-2.59$ & High \\
3 & $2.60-3.39$ & Medium \\
4 & $3.40-4.19$ & Weak \\
5 & $4.20-5.00$ & Very weak \\
\hline
\end{tabular}

\section{Data Analyses}

To answer the question of the research "What is the reality of financial independence at Prince Sattam bin Abdulaziz University according to the new university system and the 2030 vision for the Kingdom of Saudi Arabia?", the estimated statistics are presented in table 4. Table 4 shows the mean and the standard deviation for each of the phrases from the first axis. 
Table 4. Mean and the standard deviation for the phrases

\begin{tabular}{|c|c|c|c|c|c|}
\hline No. & Phrase & Mean & $\begin{array}{l}\text { Standard } \\
\text { deviation }\end{array}$ & Order & Explanation \\
\hline 1 & $\begin{array}{l}\text { The university is heavily dependent on government } \\
\text { funding for its budget. }\end{array}$ & 1.17 & .44 & 1 & Very high \\
\hline 2 & $\begin{array}{c}\text { The university is currently taking necessary measures } \\
\text { to diversify its sources of income and try to achieve } \\
\text { financial independence. }\end{array}$ & 1.80 & .91431 & 4 & High \\
\hline 3 & $\begin{array}{l}\text { The university administration has the necessary } \\
\text { components for financial independence. }\end{array}$ & 1.81 & 1.00442 & 8 & High \\
\hline 4 & $\begin{array}{l}\text { The university abounds in property, facilities and } \\
\text { endowments that enable it to financial independence if } \\
\text { it is well invested. }\end{array}$ & 1.81 & .83322 & 8 & High \\
\hline 5 & $\begin{array}{l}\text { The university needs to develop means of } \\
\text { communication between its officials and private sector } \\
\text { officials in the surrounding community. }\end{array}$ & 1.52 & 1.7 & 2 & Very high \\
\hline 6 & $\begin{array}{l}\text { The culture of donating to college education does not } \\
\text { spread to the surrounding society. }\end{array}$ & 1.80 & .86375 & 5 & High \\
\hline 7 & $\begin{array}{c}\text { The university adopts several agreements with the } \\
\text { private sector to support its budget. }\end{array}$ & 1.81 & .81963 & 9 & High \\
\hline 8 & $\begin{array}{l}\text { There are deficiencies in the regulations and laws that } \\
\text { support diversification of university funding sources. }\end{array}$ & 2.03 & .87 & 13 & High \\
\hline 9 & $\begin{array}{l}\text { There are not enough experiences for the private sector } \\
\text { to benefit from research experiences at the university. }\end{array}$ & 2.32 & 1.17 & 19 & High \\
\hline 10 & $\begin{array}{l}\text { The university conducts many training courses and } \\
\text { paid programs to diversify its sources of income to } \\
\text { achieve financial independence. }\end{array}$ & 2.03 & .89 & 14 & High \\
\hline 11 & $\begin{array}{l}\text { The university does not benefit greatly from major } \\
\text { institutions that belong to its geographical scope, such } \\
\text { as Almara'i or Al Safi. }\end{array}$ & 1.93 & .79 & 10 & High \\
\hline 12 & $\begin{array}{l}\text { University research programs are not closely related to } \\
\text { productive society institutions. }\end{array}$ & 2.16 & .82 & 16 & High \\
\hline 13 & $\begin{array}{l}\text { The university provides the necessary scientific } \\
\text { consultations to the institutions of the surrounding } \\
\text { society in order to achieve diversification of its } \\
\text { resources and financial independence. }\end{array}$ & 2.34 & .88 & 20 & High \\
\hline 14 & $\begin{array}{l}\text { The idea prevails that the state is responsible for } \\
\text { spending on university education in the university } \\
\text { community. }\end{array}$ & 1.79 & .76 & 3 & Very high \\
\hline 15 & $\begin{array}{l}\text { The research chairs currently in the university } \\
\text { contribute to enriching its budget. }\end{array}$ & 2.30 & .93 & 18 & High \\
\hline 16 & University facilities, endowments and properties can be & 1.98 & .83 & & \\
\hline
\end{tabular}


used to diversify their sources of income and achieve financial independence.

17

The university has a complete plan to try to achieve financial independence by diversifying its sources of income.

The university benefits from its human experiences in providing scientific consultations or research related to society to increase its financial resources.

There are deficiencies in marketing successful university experiences with donators.

The university holds a coordination meeting for the General Authority of Endowments and Endowments for Emerging Universities to serve society and achieve a development role through endowments.

General mean all phrases are first axis

12

High

15

High

2.06

17

High

2.16

11

High

6

High

1.93

0.48

High

The mean for all phrases of the first axis was 1.93 with a standard deviation 0.48 . The degree of approval of the research sample on this axis is high and we conclude that members of the research sample give high attention to the axis of the reality of financial independence in Saudi universities and the phrases are arranged according to the mean.

The phrase No. 1 "The university relies heavily on government funding for its budget" came first with a mean of 1.17 and a standard deviation (0.44). It means that the degree of approval of the research sample on this phrase is "very high". The phrase No. 5 "the university needs to develop the means of communication between its officials and private sector officials in the surrounding community" came at second with a mean 1.52 and a standard deviation 0.71. This means that the degree of approval of the research sample on this phrase is "very high". Also, the phrase No. 14 "which prevails the idea that the state is responsible for spending on university education in the university community" came at third rank with mean 1.79 and a standard deviation 0.76 . This means that the degree of approval of the research sample on this phrase is also "very high".

The phrase No. 15 "the research chairs currently in the university contribute to enriching its budget" came in the eighteenth rank with a mean 2.30 and a standard deviation 0.93 . This means that the degree of approval of the research sample on this phrase is "high". The phrase No. 10 "the university conducts many training courses and paid programs to diversify the resources of income in it to achieve financial independence" came at the nineteenth rank with a mean 2.32 and a standard deviation 1.17 and it means that the degree of approval of the research sample on this phrase is high. The phrase No. 13 "the university provides the necessary scientific consultations to the institutions of the surrounding community in order to achieve diversification of its sources and financial independence" came in the lowest rank with a mean 2.34 and a standard deviation 0.88 which means that the degree of approval of the research sample on this phrase is also "high".

Table 5. Test of Chi-square

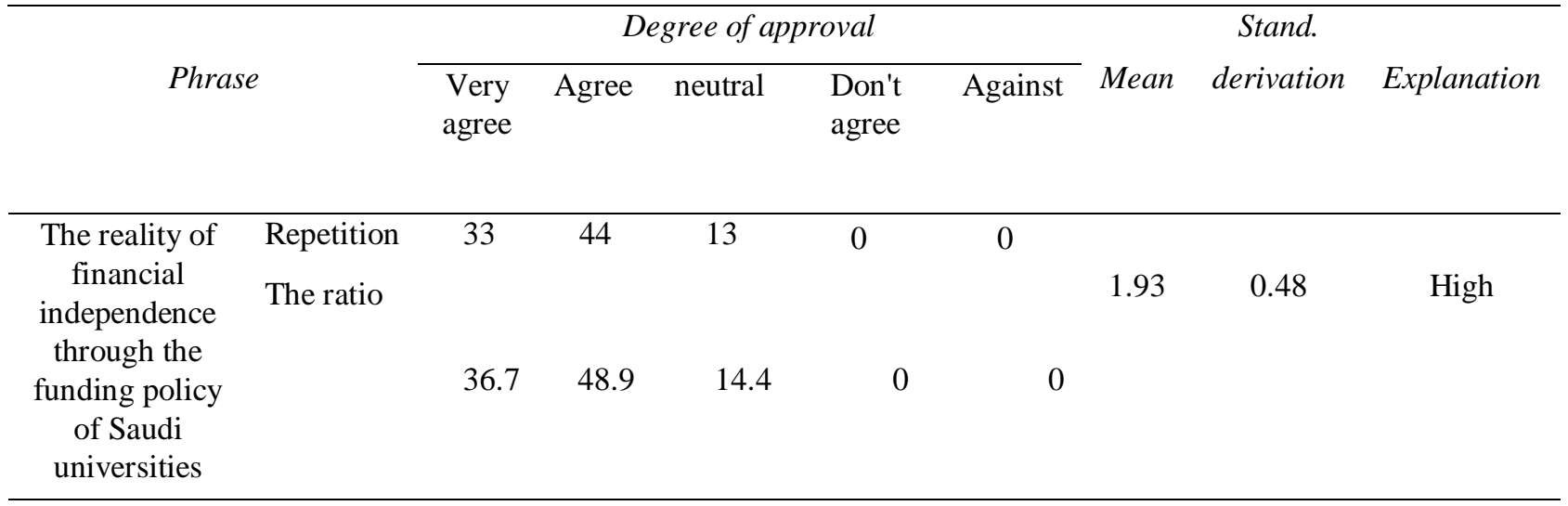




\section{Through the above table, we notice the following:}

Table 5. shows the test of Chi-square and $48.9 \%$ of the respondents agree with a high degree of financial independence through the funding policy of the Saudi universities. Further, 36.7\% of the respondents agree with a very high degree and $14.4 \%$ are neutral. The value of the average is 1.93 and it shows, in general, the members of the research sample considered the application of financial independence through the funding policy of Saudi universities to be a high degree.

Table 6. Chi-square test for matchmaking quality

\begin{tabular}{cccc}
\hline First axis & Chi-square Value & $\begin{array}{c}\text { Degrees of } \\
\text { freedom }\end{array}$ & $P$-Value \\
\hline
\end{tabular}

The reality of applying financial independence through the funding policy of Saudi universities

$\begin{array}{lll}16.47 & 2 & 0.00\end{array}$

The value of the Chi-square is reached at 16.47 with a degree of freedom 2 at $1 \%$ significant level as it is less than $1 \%$. This indicates that the individuals of the research sample consider that the reality of applying financial independence through the funding policy of Saudi universities is possible with a high degree.

It is clear from the above mentioned that the university is heavily dependent on government funding for its budget. Secondly, the university needs to develop the means of communication between its officials and private sector officials in the surrounding community. Thirdly, the idea prevails that the state is responsible for funding the university education. Saudi universities depend, for their funding resources, on the government funding as a primary funding resource as per the phrases that got the highest ranking. Moreover, the university is currently trying several procedures to obtain external funding by employing its financial and human capabilities which is evident through the least-ranked phrases. Firstly, the research Chairs currently in the university contribute to enriching its budget. Secondly, the university conducts many training courses and paid-programs to diversify its income sources in order to achieve financial independence. Lastly, the university provides the necessary scientific consultations in order to achieve diversification of its funding resources and financial independence.

To answer the second research question "What is the proposed vision for diversifying funding resources to achieve financial independence at Prince Sattam bin Abdulaziz University according to the new university system and vision 2030 in light of some global experiences?", the respondents suggested to diversify the funding sources to achieve financial independence at Prince Sattam bin Abdulaziz University. The results of related phrases are presented in table 7.

Table 7. The results of the phrases of the second axis

\begin{tabular}{lllccc}
\hline No. & Phrase & Mean & $\begin{array}{c}\text { Stand. } \\
\text { derivation }\end{array}$ & Order & Explanation \\
\hline 1 & $\begin{array}{l}\text { The university shall amend the regulations and laws } \\
\text { that guarantee it to diversify its funding sources in } \\
\text { order to achieve financial independence. }\end{array}$ & 1.56 & 1.03 & 23 & Very high \\
2 & $\begin{array}{l}\text { Taking the necessary administrative measures to } \\
\text { regulate the private sector's contributions to financing } \\
\text { the university. }\end{array}$ & 1.39 & .76 & 15 & Very high \\
3 & $\begin{array}{l}\text { Setting a future vision and a specific plan to expand } \\
\text { the university's financial resources circle. }\end{array}$ \\
4 & $\begin{array}{l}\text { Working to support productive projects by activating } \\
\text { the concept of a productive university. }\end{array}$ & 1.34 & .66 & 10 & Very high \\
5 & $\begin{array}{l}\text { Spreading the culture of donating to university } \\
\text { education and its importance in the surrounding } \\
\text { society. }\end{array}$ \\
$\begin{array}{l}\text { Exploiting the major industry institutions in the } \\
\text { society surrounding the university to support the } \\
\text { university's financial resources. }\end{array}$
\end{tabular}


7 Issuing the necessary evidence that clarifies the areas of support, their rules and advantages, and disseminating them to the society surrounding the

Very high university.

8 Developing a plan to invest in the university's buildings, facilities and laboratories to contribute to supporting the university's budget.

Expanding the start of paid academic programs at the university.

1.32

18

Very high

Benefiting from the expertise of specialists in
developing the investment side of the university.

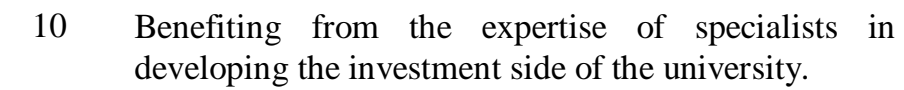

1.51

.61

$8 \quad$ Very high

11 Launching research programs for postgraduate studies compatible with the external labor market to achieve economic returns for the university.

12 Establishing service and scientific centers that suit the needs of the surrounding community.

13 Initiate distance education programs as an important source of material benefits for universities.

14 Benefiting from previous and successful experiences in financing universities and supporting them locally and internationally.

16 Supporting the entities and institutions that contributed to financing the university in an advertisement.

18 Establishing a complete communication system between university officials and private sector officials.

19 Expanding the creation of scientific chairs that are related to the interests of the community surrounding the university and the labor market.

20 Launching a forward-looking vision for the future of the university endowments.

$14 \quad$ Very high

21 Offering programs and initiatives to develop endowments at the university to achieve financial sustainability for the university.

22 Discussing the ways of achieving the integrated goals of the endowments of the university and the General Authority of Endowments at the Kingdom level through the Ministry of Education.

23 Setting a complete plan to benefit financially from the university's endowments to achieve financial returns that contribute to supporting the university's budget. 
Table 7. shows the frequencies, percentages, mean and standard deviation for the phrases of the second axis and for the axis in general. The mean for all phrases of the second axis is 1.38 with a standard deviation 0.53 and this average shows that the degree of approval of the research sample on this axis is very high. Thus, we conclude that the respondents from the research sample give a great attention to the axis of proposals to diversify funding sources to achieve financial independence in Saudi universities.

The phrase No. 15 "the marketing of successful experiences that took place between the university and the private sector" came at first with a mean of 1.27 and a standard deviation 0.65 which means that the degree of approval of the research sample on this phrase is "very high". The phrase No. 16 "Supporting entities and institutions that contributed to funding the university in an advertisement" came at second with a mean 1.28 and standard deviation 0.65 which shows that the degree of approval of the research sample on this phrase is "very high". The phrase No. 17 "publishing the foundations of the 2030 vision for education in relation to financing scientific institutions through its resources and surrounding society" came at third with a mean 1.28 and a standard deviation 0.60 which shows that the degree of approval of the research sample on this phrase is "very high".

The phrase No. 10 "to benefit from the expertise of specialists in the development of the university's investment side" came at the twenty-first rank with a mean 1.51 and a standard deviation 0.66 which shows that the degree of approval of the research sample on this phrase is "very high to some extent". The phrase No. 7 "issuing the necessary evidence that clarifies the areas of support, their rules and advantages, and publishing them in the community surrounding the university" came at the twenty-second rank with a mean 1.54 and a standard deviation 0.79 which means that the degree of approval of the research sample on this phrase is also "very high to somewhat". The phrase No. 1 "the university's amendment of regulations and laws that guarantee diversification of its funding sources to financial independence" came at a last rank with a mean of 1.56 and a standard deviation 1.03. This means that the degree of approval of the research sample on this phrase is also "very high to Somewhat".

Table 8. Chi-square

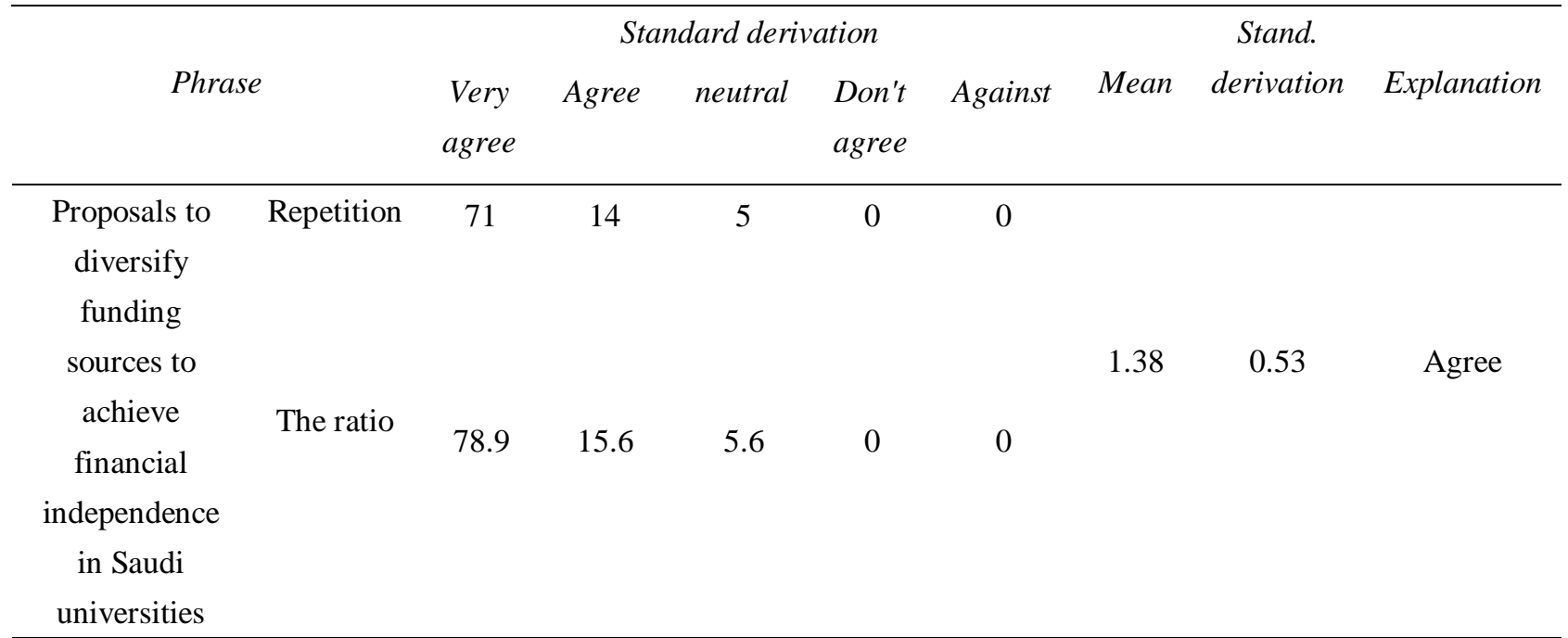

Table 8 shows that the $78.9 \%$ of the respondents agree with a high degree with the proposals to diversify funding sources to achieve financial independence in Saudi universities. The $15.6 \%$ agree with a high degree and 5.6\% are neutral. The value of the average mean is 1.38 and in general, the members of the research sample favor the proposals to diversify the funding sources to achieve financial independence in Saudi universities.

Table 9. Chi-square test for matchmaking quality

\begin{tabular}{cccc}
\hline Second axis & $\begin{array}{c}\text { The value of the Kay } \\
\text { square }\end{array}$ & $\begin{array}{c}\text { Degrees of } \\
\text { freedom }\end{array}$ & P-Value \\
\hline $\begin{array}{c}\text { Proposals to diversify funding sources to achieve } \\
\text { financial independence in Saudi universities }\end{array}$ & 55.5 & 3 & 0.000 \\
\hline
\end{tabular}

Through the table 9, we notice that the value of the Chi-square is reached to 55.5 with a degree of freedom 3 at a level of significance $1 \%$. It indicates that members of the research sample favor the proposals to diversify funding resources to achieve financial independence in Saudi universities. 
Table 10. testing the normal distribution of data

\begin{tabular}{|c|c|c|}
\hline Axis & Kolmogorov-Smirnov Z & $p$-value \\
\hline $\begin{array}{l}\text { The reality of applying financial independence through the } \\
\text { funding policy of Saudi universities }\end{array}$ & 1.24 & 0.09 \\
\hline $\begin{array}{l}\text { Proposals to diversify funding sources to achieve financial } \\
\text { independence in Saudi universities }\end{array}$ & 1.30 & 0.07 \\
\hline
\end{tabular}

From the results shown in table 10, it is cleared that there are no statistically significant differences in the two axes at the 5\% level of significance. Therefore, we accept the null-hypothesis that the data of the research sample are distributed normally with respect to the two axes and reject the alternative hypothesis of non-normal distribution. Based on these results, it is clear that the appropriate tests are conducted to verify the statistical differences of normal distribution. It is also cleared from the results that the degree of approval of the research sample on the proposals to diversify funding resources at the university according to the new university system and the vision of 2030 in light of some high international experiences are according to the phrases which got the highest ranking. These are "marketing the successful experiences which took place between the university and the private sector", "supporting the entities and institutions which contributed in funding the university through an advertisement" and "spreading the bases of the 2030 vision for education in relation to funding scientific institutions through its resources and surrounding society".

The university should also have to take some measures to diversifying its funding resources. This is evident through the least-ranked phrases which are "benefiting from the expertise of specialists in developing the investment side of the university", "issuing the necessary evidence that clarifies areas of support, their rules and advantages, and disseminating them to the society surrounding the university" and "the university shall amend the regulations and laws which guarantee it to diversify its funding resources in order to achieve financial independence".

Table 11. Analysis of Variance

\begin{tabular}{|c|c|c|c|c|c|c|c|}
\hline Variable & Axis & $\begin{array}{r}\text { Source of } \\
\text { contrast }\end{array}$ & $\begin{array}{l}\text { Sum of } \\
\text { squares }\end{array}$ & $\begin{array}{c}\text { Degrees of } \\
\text { freedom }\end{array}$ & $\begin{array}{l}\text { Average } \\
\text { squares }\end{array}$ & Value of $F$ & $P$-Value \\
\hline \multirow{6}{*}{ Experience } & \multirow[t]{2}{*}{ First } & $\begin{array}{c}\text { Between } \\
\text { groups }\end{array}$ & 5.228 & 4 & 1.307 & 7.408 & $.000 *$ \\
\hline & & $\begin{array}{l}\text { Within } \\
\text { groups }\end{array}$ & 14.996 & 85 & .176 & \multirow{5}{*}{5.419} & \multirow{5}{*}{$.001 *$} \\
\hline & \multirow{4}{*}{ Second } & Total & 20.224 & 89 & & & \\
\hline & & $\begin{array}{c}\text { Between } \\
\text { groups }\end{array}$ & 5.017 & 4 & 1.254 & & \\
\hline & & $\begin{array}{l}\text { Within } \\
\text { groups }\end{array}$ & 19.671 & 85 & .231 & & \\
\hline & & Total & 24.688 & 89 & & & \\
\hline \multirow{6}{*}{ Job title } & \multirow{3}{*}{ First } & $\begin{array}{c}\text { Between } \\
\text { groups }\end{array}$ & 10.215 & 2 & 5.107 & \multirow[t]{3}{*}{44.391} & \multirow[t]{3}{*}{$.000 *$} \\
\hline & & $\begin{array}{l}\text { Within } \\
\text { groups }\end{array}$ & 10.009 & 87 & .115 & & \\
\hline & & Total & 20.224 & 89 & & & \\
\hline & \multirow{3}{*}{ Second } & $\begin{array}{c}\text { Between } \\
\text { groups }\end{array}$ & 15.724 & 2 & 7.862 & \multirow[t]{3}{*}{76.302} & \multirow[t]{3}{*}{$.000 *$} \\
\hline & & $\begin{array}{l}\text { Within } \\
\text { groups }\end{array}$ & 8.964 & 87 & 103 & & \\
\hline & & Total & 24.688 & 89 & & & \\
\hline
\end{tabular}

$(*)$ Means there are statistically significant differences at the level of significance $(0.01)$ or less 
Table 11. shows the result of Analysis of Variance based on One Way ANOVA. The result shows that there are statistically significant differences at $5 \%$ level of significance. The difference in opinions of the research sample for the two subjects of the research (first and second) is significant due to the experience and job title. This indicates that the research sample with experience more than 10 years is more consistent with the axis of the reality of financing in Saudi universities than that the experience of 10 years. The research sample with leadership positions is more in agreement with proposals to diversify funding resources at Prince Sattam bin Abdulaziz University than those who hold administrative positions or employees in the university's financial management.

\section{Conclusions and Recommendations}

Based on our investigation, the university needs to develop the means of communication between officials and private sector officials. The community surrounding the university in Al-Kharj Governorate is considered as a productive industrial society, and there are many international companies available in the governorate such as Almarai, Al-Safi, and other companies. The Al-Kharj region represents the best regions of the Kingdom of Saudi Arabia in terms of agricultural production, and therefore it is an attractive environment for many businessmen and capitalists, and the means of communication play its vital role in defining the community surrounding the societal role that the university can play in developing community members and improving the job market. The idea prevails that the state is responsible for spending on university education in the university community. It is one of the misconceptions that prevail not only in the community of Prince Sattam bin Abdulaziz University, but also in Saudi society in general. The prevailing concept is that the university is a governmental institution which receives the full governmental fund from the state of Saudi Arabia. But with the current development and the increasing need for many potentials and self-funding resources to cover the expenses of the university, this mistaken view should change. Also, the full independence of the university in its decision-making is not achieved unless it has sufficient resources to make it an independent university which is capable of relying, in one way or another, on its own and societal resources.

The university should improve the mechanisms that represent lower percentages in studying the actual reality of the university's funding, and considering them as weaknesses that require work on improving them. For example, the research chairs, currently in the university, contribute to enriching its budget in view of the experiences reviewed in the body of the research. We find that Japan's experience in diversifying funding resources was one of its priorities is the scientific chair because of these scientific and material benefits of the university. It is one of the strongest measures that it can contribute to the university's renaissance scientifically and financially. The university should conduct training courses and paid programs to diversify its income resources. It is possible to diversify, contrast and accompany the courses to the labor market in the external community to increase their demand, and the university's human resources may play a vital role in setting up courses, workshops and paid programs. The university should provide the necessary scientific consultations to the surrounding community institutions. It is one of the important sources for the university, and this resource has already been activated through the "Research and Consulting Services Institute". Marketing the successful experiences should place between the university and the private sector. Marketing may play the biggest factor in achieving success, and the university is currently moving towards vitalizing this axis through the "Public Relations and Media Department of the university. This represents a great starting point for the university towards communicating with the surrounding community and highlighting the agreements which are made signed to educate the importance of cooperation between the private sector and the university.

The entities and institutions should contribute to funding the university in an advertisement. This represents an incentive for many parties, especially commercial and industrial ones to cooperate with the university and strive to conclude agreements with it. Publication of the 2030 vision for education in relation to financing scientific institutions should be considered for society because it is very important to work on publishing these indicators related to improving the funding resources of the educational sector.

The university should be benefited from the expertise of specialists in the development of the university's investment side. This university has a presence within a first-class industrial society, and businessmen play an important role in developing the governorate which can be invested heavily in developing the university's resources through their expertise and successful experiences. Issuing the necessary confirmation may also clarify the fields of support, its rules and advantages, and disseminating it to the surrounding community of the university. Some people may be ignorant of how to cooperate with the university to benefit it and benefit from its potentials, and therefore, the presence of confirmation that clarifies these rules makes it easier for them to know the basic lines of dealing and cooperation with the university. The university should amend the regulations and laws that guarantee its 
diversification of funding resources. This can be done through the flexibility in the university's financial and administrative systems.

The university should consider the proposals for diversification of funding resources in Saudi universities, which were reached by the research, taking into consideration the internal and external factors of each university. The university should create a specialized committee to study how to benefit from its human and financial capabilities. The university's departments or individuals should be motivated to invest in the university in accordance with the rules and regulations. The experience and competent personnel should be hired for university marketing. The university should pay attention to the endowments of universities. The university should convert of some units in the university to units of a special nature that serve the external community and financially benefit the university, such as the Statistical Information Center, the Center for University Education Development, and others. The paid training department can be carried out by faculty members under the supervision of the university's training unit.

\section{Acknowledgment}

This project was supported by Deanship of Scientific Research at Prince Sattam bin Abdulaziz University Alkharj under the project No. 2019/02/10265

\section{References}

Ahmad, M. \& Al-Dabbasi, M. H. (2016). Financing institutions of higher education. Dar Al-Messila: Kuwait.

Al-Dawood, A. M. S. (2017). The responsibility of Saudi universities in achieving the Kingdom's 2030 vision. Conference of the role of Saudi universities in activating the Kingdom's 2030 Vision, Qassim University.

Al-Fahad, Z. F. (2017). Funding Department for Governmental Universities in the Kingdom of Saudi Arabia in the light of the experiences of universities in the United Kingdom and the Hashemite Kingdom of Jordan (a comparative study). $\mathrm{PhD}$ thesis, Department of Educational Administration and Planning, College of Social Sciences, Imam Muhammad bin Saud Islamic University: Riyadh.

Al-Hajji, I. M. \& Dokki, A. (2015). Endowment for education in the West. Education Endowment Foundation, London.

Al-Hammadi, F. S. \& Samah, M. (2017). Self-development of Saudi universities. Conference of the role of Saudi universities in activating the vision of 2030, Qassim University, 936-980.

Al-Harbi, M. (2015). Suggested alternatives to financing education in education, public universities in the Kingdom of Saudi Arabia. Journal of the Faculty of Education, 103(1), 1-35.

Al-Harout, A. (2010). Arab Universities Reform: A Developmental Approach to the Relationship with Society. The Third Arab Conference on Arab Universities: Challenges and Prospects, Arab Administrative Development Organization, Sharm El-Sheikh, Egypt.

Al-Jumai, W. A. (2019). Contemporary Global Trends in Funding Higher Education: The British Model, A Theoretical Vision. The Arab Foundation for Scientific Consultation and Human Resources Development.

Al-Khazim, M. A. (2018). University of 2030: A vision of the transformation of Saudi universities. Arab Science House Publishers: Beirut.

Al-Majid, I. H. (2018). A proposed scenario for financing Saudi universities in the light of the university's productive philosophy. PhD thesis, Department of Foundations of Education, College of Social Sciences, Imam Muhammad bin Saud Islamic University: Riyadh.

Al-Maliki, A. S. (2014). Alternatives to financing higher education in the Kingdom of Saudi Arabia. Saudi Journal of Higher Education, 12, 1-23.

Al-Otaibi, F. A. (2004). Private Sector Contribution to Financing Public Education in the Kingdom of Saudi Arabia. Unpublished Master Thesis, Department of Educational Administration, College of Education, King Saud University, Riyadh.

Al-Tuwairqi, N. S. (2012). Sources of funding for higher education in the Kingdom of Saudi Arabia and Saudi Arabia, a comparative study. Journal of Arab Studies in Education and Psychology, 24(1), 263-287.

Al-Wadhani, J. A. (2007). Knowledge Management an Introduction to Achieving a University Form Producing. Master Thesis, Department of Educational Administration and Planning. Faculty of Education. Umm Al Qura University, Makkah.

Al-Zamil, H. A. (2018). The sufficiency of self-financing alternatives at Imam Muhammad bin Saud Islamic 
University. Master's thesis, Department of Educational Administration and Planning, College of Social Sciences, Mohammed bin Saud Islamic University, Riyadh.

Amran, F. H., Rahman, I. K. A., Saleh, K., Ahmad, S. N. S. \& Haron, N. H. (2014). Funding Trends of Research Universities in Malaysia. Procedia Social and Behavioral Sciences, 31, 126-134. https://doi.org/10.1016/j.sbspro.2014.11.060

Bamakhurma, A. S. \& Batih, M. O. (2008). The Non-Profit University in Islamic Countries: A Proposed Form. The Second Arab Conference: Arab Universities Challenges and Ambition. Arab Administrative Development Organization: Morocco.

de Fanelli, A. G. (2009). The funding of Higher Education in Argentina. International Higher Education, 14(2), 1-23. https://doi.org/10.6017/ihe.1999.14.6458

El-Dokki, N. E. D. (2015). Financing higher education in the Arab world. The Fifth Conference of Ministers and Officials in Higher Education and Scientific Research in the Arab World, Egypt: Alexandria.

El-Sayed, M. S. N. (2003). Issues in Higher and University Education. Ayat Center for Printing, Riyadh.

Huang, F. (2016). Changes and challenges to higher education financing in Japan. Centre for Global Higher Education. working paper series, London.

Malpas, J. (2003). Performance Basied Funding methodologies-the HKU Experience. Seminar on External Funding and University Autonomy, Jane University and the OECD Program on Institutional Management in Higher Education, Oslo.

Prince Sattam bin Abdulaziz University Strategic Plan (2018). Strategic Plan 2030, Second Edition.

Rie, A. (2009). Economic Crises Accelerates the Reform of Higher Education in Thailand. International Higher Education, 11(5), 9-10.

Shehata, A. (2006). The issue of financing higher education in Egypt: the reality and the future, researches of the Higher Education Conference in Egypt, a map of reality and the orientation of the future. The eighteenth conference of research and political studies, Egypt.

Sherif, M. (2012). Independence of the Egyptian universities in light of the experiences of some countries, international charters and declarations. Educational Journal, 32, 1-35. 